\title{
Penerapan Media Pembelajaran Interaktif Berbasis Ispring pada Materi Sejarah Komputer
}

\section{Dochi Ramadhani ${ }^{1 *}$, Umi Liwayanti ${ }^{2}$}

${ }^{12}$ Program Studi Pendidikan Teknologi Informasi dan Komputer, IKIP PGRI Pontianak, Indonesia *e-mail: emaildochi@gmail.com

\begin{abstract}
Abstrak
Kurangnya media pembelajaran yang membantu mahasiswa dalam belajar membuat mahasiswa kesulitan dalam memahami materi pelajaran. Tujaun penelitian ini yaitu untuk menganalisis gambaran kreativitas dan hasil belajar mahasiswa, peningkatan kreativitas dan hasil belajar mahasiswa sebelum dan sesudah menggunakan media pembelajaran berbasis ispring pada materi sejarah komputer. Metode penelitian yang digunakan yaitu penelitian eksperimen dengan desain penelitian yaitu quasi eksperimental design. Teknik pengumpulan data yang digunakan yaitu kuesioner dan tes hasil belajar yang diberikan kepada 65 mahasiswa. Teknik analisis data yaitu menggunakan statistic deskriptif dan uji t untuk uji hipotesis. Berdasarkan hasil analisis data diketahui bahwa rata-rata nilai kreativitas mahasiswa yaitu 53,26 untuk kelas kontrol dan 52,80 untuk kelas eksperimen. Dan rata-rata nilai hasil belajar mahasiswa sebelum yaitu 37,14 untuk kelas eksperimen dan 24,33 untuk kelas kontrol, rata-rata nilai hasil belajar mahasiswa sesudah yaitu 46,14 untuk kelas eksperimen dan 36,29 untuk kelas kontrol. Terdapat peningkatan kreativitas mahasiswa setelah menerapkan media pembelajaran yaitu $21,50 \%$ pada kelas eksperimen dan $19,65 \%$ pada kelas control. Terdapat peningkatan hasil belajar siswa sebelum dan sesudah diterapkan media pembelajaran berbasis ispring pada materi sejarah dengan perbedaan nilai pretest dan posttest sebesar 11,96. Implikasi penelitian ini membantu siswa dalam belajar sehingga hasil belajar siswa meningkat.
\end{abstract}

Kata kunci: media pembelajaran, ispring, kreativitas

\begin{abstract}
Lack of learning media that helps students in learning makes it difficult for students to understand the subject matter. This study aims to analyze the description of creativity and student learning outcomes, increased creativity and student learning outcomes before and after using ispring-based learning media on computer history material. The research method used is experimental research with a quasi-experimental design. The data collection techniques used were questionnaires and learning outcome tests given to 65 students. The data analysis technique used descriptive statistics and t-test to test the hypothesis. Based on the results of data analysis, it is known that the average scores of student creativity is 53.26 for the control class and 52.80 for the experimental class. And the average scores of student learning outcomes before is 37.14 for the experimental class and 24.33 for the control class, the average scores of student learning outcomes after is 46.14 for the experimental class and 36.29 for the control class. There was an increase in student creativity after applying learning media, namely $21.50 \%$ in the experimental class and $19.65 \%$ in the control class. There was an increase in student learning outcomes before and after the application of ispring-based learning media on historical material with a difference in pretest and posttest scores of 11.96. The implication of this research is to help students in learning so that student learning outcomes increase.
\end{abstract}

Keywords: learning media, ispring, creativity

\footnotetext{
${ }^{*}$ Corresponding author.

Received 30 Januari 2021; Accepted 1 Maret 2021; Available online 8 April 2021 (C) 2021 MI All Rights Reserved
} 


\section{Pendahuluan}

Pendidikan merupakan salah satu penunjang keberhasilan suatu bangsa, sehingga pendidikan dapat diperlukan untuk pengembangkan potensi sumber daya manusia dalam penguasaan kompetensi keahlian dalam kaitannya dengan IImu Pengetahuan dan Teknologi (IPTEK) (Mustafa, Murniati, \& Niswanto, 2018; Wulandari, Sudatha, \& Simamora, 2020; Wungguli \& Yahya, 2020). Melalui pendidikan akan meningkatkan berpikir kreatif pada peserta didik. Berpikir kreatif tertuang dalam tujuan pendidikan nasional yang intinya ingin mengembangkan peserta didik berilmu, memiliki akhlak mulia, kreatif dan mandiri, dan menekankan kemampuan untuk memilih, mendapatkan, serta mengolah informasi secara efektif (Moma, 2017; Nada, Utaminingsih, \& Ardianti, 2018). Pendidikan mengupayakan seseorang kearah yang lebih baik sehingga berguna untuk dimasa depan (Renny dan Sonbay, 2019). Pendidik merupakan fasilitator dalam membantu peserta didik mentranformasikan potensi menjadi keterampilan yang dapat dikembangkan dan bermanfaat bagi kehidupan manusia. Pada proses pembelajaran seorang pendidik (dosen) dituntun untuk memberikan inovasi baru agar peserta didik (mahasiswa) mampu mendapatkan pengalaman baru. Inovasi ini diperlukan agar proses pembelajaran dapat menyenangkan dan manarik. Dalam mencapai tujuan pembelajaran yang diinginkan diperlukan pembelajaran yang bermakna bagi peserta didik. Faktor yang mempengaruhi pembelajaran bermakna yaitu minat dan motivasi siswa dalam belajar, dan kesiapan pengajar dalam merancang dan mempersiapankan proses pembelajaran (Donas \& Elhefni, 2016). Saat ini guru dituntut untuk dalam berinovasi dalam menggunakan model ataupun menerapkan media pembelajaran yang tepat bagi siswa sehingga tujuan pembelajaran dapat tercapai dengan maksimal.

Permasalahan yang terjadi saat ini yaitu masih banyak guru yang menggunakan model pembelajaran konvensional (Antara, Kristiantari, \& Suadnyana, 2017; Dewi, 2017; Santra, Putu, Citra Wibawa, \& Rati, 2018). Guru yang menggunakan model pembelajaran konvensional seperti ceramah akan membuat siswa merasa bosan dalam belajar (Dadri \& Putra, 2017; Lestari, Kristiantari, \& Ganing, 2017). Selain itu, masih banyak guru yang kurang menerapkan media pembelajaran didalam kelas sehingga siswa kesulitan dalam menyerap informasi yang disampaikan oleh guru (Gunawan, Sahidu, Harjono, \& Suranti, 2017; Wulandari et al., 2020). Permasalahan tersebut berpengaruh pada hasil belajar siswa yang rendah. Permasalahan ini juga ditemukan pada salah satu perguruan tinggi. Berdasarkan hasil observasi dan wawancara di IKIP PGRI Pontianak ditemukan permasalahan yakni masih banyak dosen yang tidak menerapkan media pembelajaran saat mengajar di kelas. Hal ini disebabkan karena kurangnya media pembelajaran yang dapat membantu mahasiswa dalam belajar. Hal ini berpengaruh pada rendahnya hasil belajar mahasiswa khususnya pada program studi P.TIK. Dosen masih mengajar menggunakan metode ceramah dengan berbantuan papan tulis yang masih tergolong konvensional. Metode tersebut dirasa sudah tidak sesuai lagi, hal ini disayangkan mengingat di era teknologi informasi banyak software dan hardware yang dapat diterapkan sebagai sarana pengembangan media pembelajaran. Keterampilan memilih, menggunakan, dan menyesuaikan media yang digunakan dalam proses pembelajaran merupakan permasalahan bagi setiap dosen. Dalam masalah ini terdapat beberapa hal yang perlu diperhatikan dalam penguasaan pengetahuan tentang media pendidikan ntuk mempertinggi kualitas dan efektifitas pengajaran.

Saat ini dosen dituntut untuk berinovasi dalam pembelajaran sehingga tujuan pembelajaran dapat tercapai secara maksimal. Merancang pembelajaran yang inovatif merupakan tantangan bagi dosen. Inovasi dapat berupa media pembelajaran dan metode pembelajaran. Media merupakan alat sebagai perantara untuk menyampaikan informasi pembelajaran dari dosen ke mahasiswa (Karo-Karo \& Rohani, 2018; Siddiq, Sudarma, \& Simamora, 2020). Media pembelajaran seperti: animasi, video, dan multimedia, belum dimanfaatkan dalam proses pembelajaran. Penggunaan media pembelajaran dapat meningkatkan minat dan kreativitas, membangkitan motivasi dan rangsangan 
pembelajaran, serta memberikan pengaruh psikologis pembelajaran (Herayanti, Habibi, \& Fuaddunazmi, 2017; Puspitorini, Subali, \& Jumadi, 2014). Pemanfaatan media pembelajaran bagi dosen dapat mengkonkritkan konsep atau gagasan dan memootivasi mahasiswa, sedangkan bagi maahsiswa menjadi jembatan untuk berpikir kritis. Dengan demikian media pembelajaran dapat membantu tugas dosen dan mahasiswa mencapai kompetensi dasar yang telah ditetapkan.

Salah satu media pembelajaran yang dapat diterapkan dosen dalam meningkatkan hasil belajar siswa adalah multimedia. Multimedia dapat membantu siswa dalam belajar sehingga dapat meningkatkan hasil belajar siswa (Geni, Sudarma, \& Mahadewi, 2020; Kuswanto \& Walusfa, 2017). Ispring merupakan sebuah media pembelajaran berbasis ICT atau multimedia untuk pembuatan soal, kuis/tes secara online dan offline. Salah satu point penting didalam aplikasi Ispring adalah dalam pembuatan soal ujian atau quiz interaktif dengan berbagai macam/jenis pertanyaan/soal seperti: True/False, Multiple Choice, dan Multiple response. Berdasarkan penelitian Primasari, Zulfiani, \& Herlanti (2014) menunjukkan bahwa media yang digunakan oleh tenaga pendidik pada pembelajaran biologi adalah ICT atau multimedia, media gambar, dan media gambar bergerak. Multimedia banyak digunakan karena sudah terbukti dapat meningkatkan kemauan peserta didik dalam pembelajaran dengan rata - rata $47 \%$.

Penelitian yang dilakukan oleh Ariyanti, Mustaji, \& Harwanto (2020) menyatakan bahwa diperoleh presentase kevalidan oleh ahli isi/materi pembelajaran $94 \%$, presentase oleh ahli Desain pembelajaran $84 \%$, presentase oleh ahli media sebesar $82 \%$ dan respon peserta didik diperoleh presentase dari subjek uji perorangan sebesar $88 \%$, uji kelompok kecil sebesar $85 \%$, dan uji kelompok besar menunjukkan presentase 87\%. Media pembelajaran telah memenuhi kriteria, peserta didik mencapai nilai ketuntasan. Peningkatan hasil belajar ekonomi yang dapat disimpulkan bahwa multimedia interaktif berbasis iSpring Suite8 yang dikembangkan bersifat valid, praktis, dan efektif. Penelitian yang dilakukan oleh Susiana \& Wening (2015) dan Riyanto \& Gunarhadi (2017) juga menyatakan bahwa multimedia memudahkan siswa dalam belajar karena terdapat beberapa aspek seperti audio dan visual sehingga memudahkan siswa dalam menyerap informasi pembelajaran. Dapat disimpulkan bahwa multimedia dapat membantu mahasiswa dalam belajar sehingga dapat meningkatkan hasil belajar mahasiswa.

Berdasarkan penelitian tersebut, maka akan dilakukan penelitian tentang media pembelajaran berbasis ispring untuk melihat bagaiaman penerapannya didalam proses pembelajaran terutama pada mahasiswa Program Studi Pendidikan Teknologi Informasi dan Komputer pada materi sejarah komputer. Tujuan penelitian ini adalah untuk menganalisis gambaran kreativitas dan hasil belajar mahasiswa, peningkatan kreativitas dan hasil belajar mahasiswa sebelum dan sesudah menggunakan media pembelajaran berbasis ispring pada materi sejarah komputer. Diharapkan multimedia pembelajaran dapat membantu siswa dalam belajar sehingga dapat meningkatkan hasil belajar mahasiswa.

\section{Metode}

Metode yang digunakan dalam penelitian ini adala quasi eskperimental design. Quasi eksperimen digunakan karena penelitian menggunakan kelompo kontrol dan kelompok eksperimen dalam memenuhi data.Variabel penelitian terdiri dari variabel bebas dan variabel terikat. Variabel bebas yaitu media pembelajaran interaktif, sedangkan variabel terikat yaitu kreativitas dan hasil belajar mahasiswa. Populasi penelitian adalah mahasiswa semester 4 Program Studi P.TIK IKIP PGRI Pontianak yang terdiri dari 5 kelas dengan jumlah 131 mahasiswa. Teknik sampling yang digunakan yaitu Teknik purposive sampling. Berdasarkan teori tersebut, maka pertimbangan yang dipilih adalah kecakapan mahasiswa selama pembelajaran. Oleh karena itu, maka sampel yang digunakan dalam penelitian adalah kelas B Pagi dan B Sore dengan jumlah sampel 65 mahasiswa. 
Teknik pengumpulan data penelitian menggunakan teknik kuesioner dan pengukuran. Alat yang digunakan untuk mengumpulkan data yaitu angket dan tes hasil belajar. Setelah data terkumpul, maka selanjutnya data tersebut akan di analisis menggunakan statistic deskriptif, persentase, dan uji T. Statistic deskriptif digunakan untuk mengetahui gambaran data terkait variabel penelitian. Persentase digunakan untuk mencari persentase peningkatan kreativitas sebelum dan sesudah menerapkan media pembelajaran interaktif. Dan, uji T digunakan untuk menguji peningkatan hasil belajar sebelum dan sesudah menerapkan media pembelajaran interaktif. Sebelum dilakukan perhitungan persentase dan ui T, data tersebut terlebih dahulu dilakukan uji persyaratan analisis menggunakan uji normalitas dan uji homogenitas. Pengujian persyaratan analisis dilakukan untuk mengetahui data tersebut normal dan homogen atau tidak.

\section{Hasil dan Pembahasan}

Kreativitas merupakan kemampuan yang dimiliki oleh mahasiswa untuk menciptakan suatu ide, gagasan dan pikiran terhadap suatu bidang ilmu. Berdasarkan data yang diperoleh, diperoleh hasil perhitungan deskriptif kreativitas sebagai berikut:

Tabel 1. Hasil Perhitungan Deskriptif Kreativitas

\begin{tabular}{lll}
\hline Deskriptif & Kelas Kontrol & Kelas Eksperimen \\
\hline Mean & 53,26 & 52,80 \\
Median & 53 & 52 \\
Modus & 53 & 52 \\
\hline
\end{tabular}

Berdasarkan tabel diatas diketahui nilai rata-rata kreativitas kelas kontrol sebesar 53,26 , nilai median sebesar 53 , modus sebesar 53 , dan nilai standar deviasi sebesar 3,390 . Sedangkan, kelas eksperimen diketahui nilai rata-rata kreativitas sebesar 52,80 , nilai median sebesar 52 , modus sebesar 52 , dan nilai standar deviasi sebesar 4,639. Hasil perhitungan diatas dapat dilihat pada gambar 1.

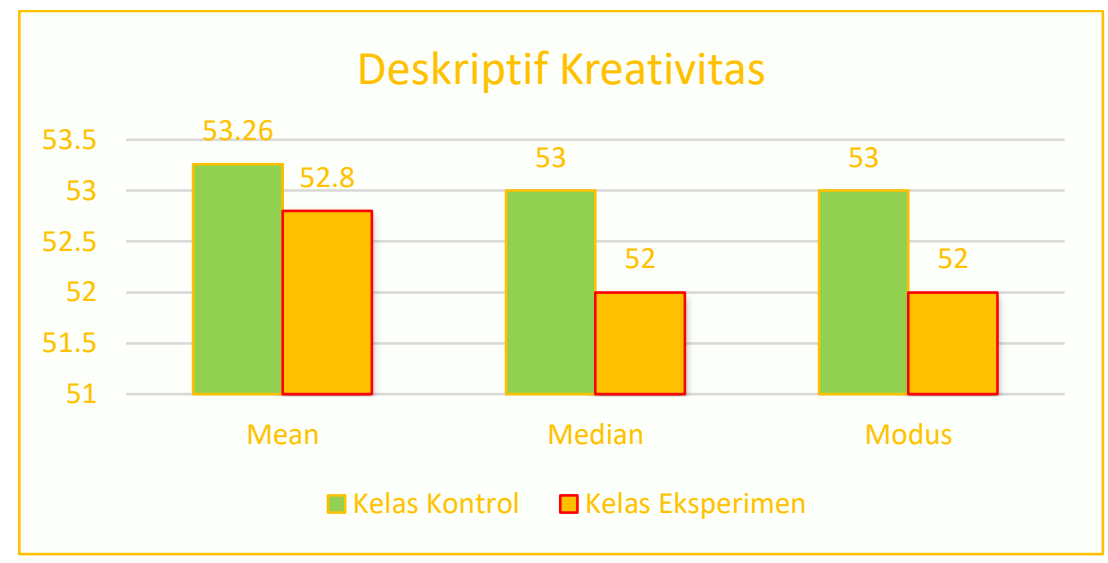

Gambar 1. Histogram Deskriptif Kreativitas

Hasil belajar merupakan kemampuan yang dimiliki oleh mahasiswa untuk mengubah perilaku dan menghasilkan perubahan pengetahuan dalam aspek kognitif. Tes yang diberikan berupa soal pilihan ganda, dimana setiap soal yang diberikan merupakan materi yang belum diajarkan oleh dosen agar dapat mengetahui kemampuan dasar yang dimiliki oleh peserta didik. Hasil belajar yang dinilai adalah hasil belajar sebelum (pretest) dan sesudah (posttest) menerapkan media pembelajaran interaktif ispring. Berikut hasil perhitungan deskriptif pretest dan posttest kelas control dan kelas eksperimen. Hasil perhitungan diatas dapat dilihat pada gambar 2 . 
Tabel 2. Hasil Perhitungan Deskriptif Hasil Belajar

\begin{tabular}{ccccc}
\hline \multirow{2}{*}{ Deskriptif } & \multicolumn{2}{c}{ Kelas Eksperimen } & \multicolumn{2}{c}{ Kelas Kontrol } \\
\cline { 2 - 5 } & Pretest & Posttest & Pretest & Posttest \\
\hline Mean & 37,14 & 46,14 & 24,33 & 36,29 \\
Median & 36,67 & 46,67 & 21,67 & 38,33 \\
Modus & 32 & 47 & 20 & 38 \\
\hline
\end{tabular}

Data pretest kelas eksperimen memiliki nilai rata-rata sebesar 37,14 , median sebesar 36,67 dan modus sebesar 32. Data pretest kelas kontrol memiliki nilai rata-rata sebesar 24,33, median sebesar 21,67 dan modus sebesar 20. Berikutnya, data posttest kelas eksperimen memiliki nilai rata-rata sebesar 46,14, median sebesar 46,67 dan modus sebesar 47. Data posttest kelas kontrol memiliki nilai rata-rata sebesar 36,29, median sebesar 38,33 dan modus sebesar 38 . Hasil perhitungan diatas dapat dilihat pada gambar 2:

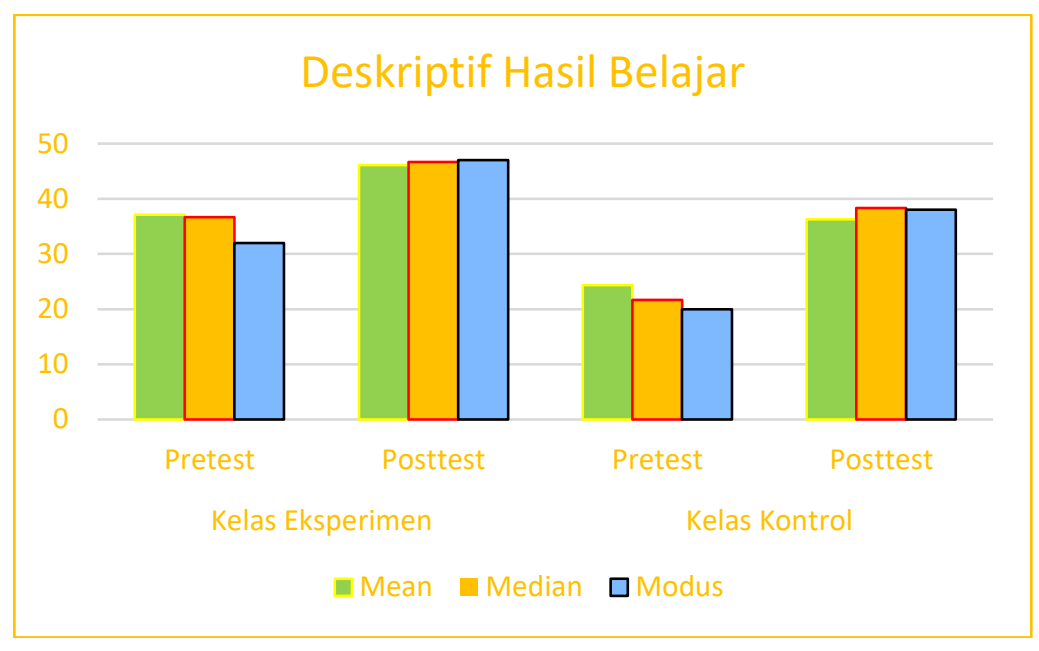

Gambar 2. Histogram Hasil Belajar

Sebelum melakukan uji hipotesis, data terlebih dahulu di uji prasyarat analisis untuk menguji data yang diperoleh apakah sudah memenuhi persyaratan untuk dilakukan uji hipotesis. Uji prasyarat analisis yang digunakan yaitu uji normalitas dan uji homogenitas. Uji normalitas yaitu uji prasyarat yang dilakukan untuk melihat normal atau tidaknya data yang diperoleh. Uji Normalitas berguna untuk menentukan data yang telah dikumpulkan berdistribusi normal atau diambil dari populasi normal. Data dapat dikatakan normal jika nilai sig $>0,05$. Berikut hasil uji normalitas data:

Tabel 3. Hasil Uji Normalitas Data

\begin{tabular}{ccc}
\hline Shapiro-Wilk & Statistic & Sig \\
\hline Kelas Kontrol & 0,948 & 0,1 \\
Kelas Eksperimen & 0,951 & 0,119 \\
\hline
\end{tabular}

Berdasarkan hasil uji normalitas diatas, diketahui bahwa sig kelas control yaitu 0,1 $>0,05$, sedangkan sig kelas eksperimen yaitu $0,119>0,05$ sehingga dapat ditarik kesimpulan bahwa data berdistribusi normal.

Uji prasyarat berikutnya yang digunakan dalam penelitian adalah uji homogenitas. Uji Homogenitas bertujuan untuk mengetahui variasi data dari suatu populasi memiliki varians yang sama atau tidak. Asumsi yang mendasari dalam Analisis of Varians (ANOVA) yaitu bahwa varians dari beberapa populasi adalah sama atau homogen. Uji 
homogenitas sebagai bahan acuan untuk menentukan keputusan uji statistik. Data dikatakan homogen jika nilai sig $>0,05$. Berikut hasil uji homogenitas data:

Table 4. Hasil Uji Homogenitas Data

\begin{tabular}{ccc}
\hline & Levene Statistic & Sig \\
\hline Nilai Based on Mean & 3,549 & 0,064 \\
\hline
\end{tabular}

Berdasarkan hasil uji homogenitas diatas, diketahui bahwa nilai sig dari rata-rata pada nilai di kelas kontrol dan kelas eskperimen sebesar 0,064. Karena hasil Sig > 0,05 $(0,064>0,05)$ dapat disimpulkan bahwa varians data nilai pada kelas kontrol dan kelas eksperimen adalah sama atau homogen. Data yang diperoleh dinyatakan normal dan homogen sehingga dapat digunakan untuk uji hipotesis penelitian.

Uji hipotesis merupakan uji yang dilakukan untuk menjawab rumusan masalah dalam penelitian. Peningkatan kreativitas mahasiswa dihitung menggunakan persentase berdasarkan data hasil angket yang telah disebarkan. Angket kreativitas diberikan sebelum dan sesudah menerapkan media pembelajaran interaktif ispring pada kelas kontrol dan kelas eksperimen. Berikut hasil perhitungan peningkatan kreativitas yang disajikan dalam gambar histogram:

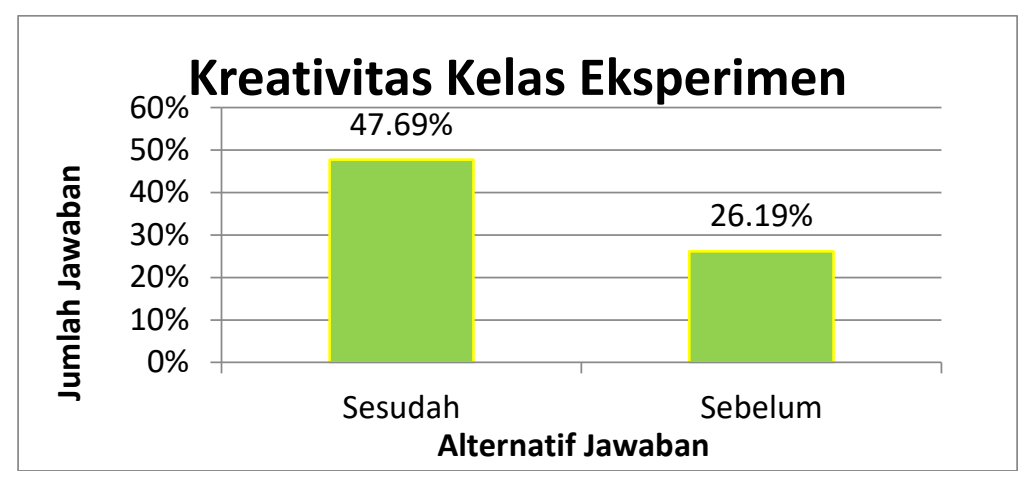

Gambar 3. Histogram Peningkatan Kreativitas Kelas Eksperimen

Gambar 3 menunjukkan bahwa kreativitas yang dimiliki mahasiswa sebelum diberikan perlakuan berjumlah $26,19 \%$, sedangkan kreativitas yang dimiliki mahasiswa setelah diberikan perlakuan berjumlah $47,69 \%$. Berdasarkan diagram tersebut dapat disimpulkan bahwa kreativitas mahasiswa pada kelas eksperimen mengalami peningkatan sebesar $21,50 \%$.

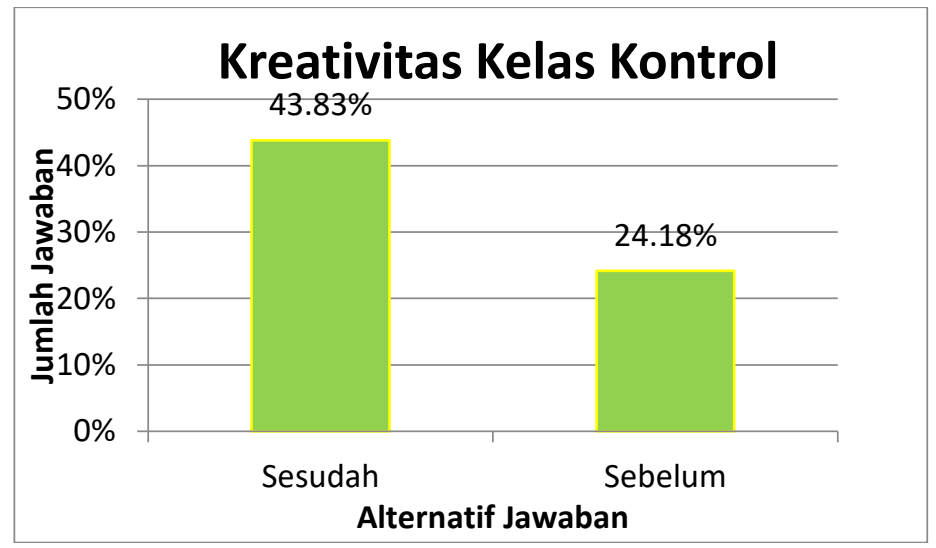

Gambar 4. Histogram Peningkatan Kreativitas Kelas Kontrol 
Gambar 4 menunjukkan bahwa kreativitas yang dimiliki mahasiswa sebelum diberikan perlakuan berjumlah $24,18 \%$, sedangkan kreativitas yang dimiliki mahasiswa setelah diberikan perlakuan berjumlah $43,83 \%$. Berdasarkan diagram tersebut dapat disimpulkan bahwa kreativitas mahasiswa pada kelas kontrol mengalami peningkatan sebesar $19,65 \%$.

Uji hipotesis yang digunakan dalam penelitian adalah Paired T-Test untuk mencari peningkatan hasil belajar mahasiswa sebelum dan sesudah diterapkan media pembelajaran interaktif berbasis ispring. Paired T-Test adalah salah satu pengujian hipotesis menggunakan data yang memiliki hubungan pada setiap sampel.

Table 5. Paired T-Test Kelas Eksperimen

\begin{tabular}{|c|c|c|c|c|c|c|c|c|}
\hline & \multicolumn{8}{|c|}{ Paired Differences } \\
\hline & \multirow[t]{2}{*}{ Mean } & \multirow[t]{2}{*}{$\begin{array}{c}\text { Std. } \\
\text { Deviasi }\end{array}$} & \multirow{2}{*}{$\begin{array}{l}\text { Std. } \\
\text { Error } \\
\text { Mean }\end{array}$} & \multicolumn{2}{|c|}{$\begin{array}{l}95 \% \text { Confidence } \\
\text { Interval of the } \\
\text { Difference }\end{array}$} & \multirow[t]{2}{*}{$\mathbf{T}$} & \multirow[t]{2}{*}{ Df } & \multirow[t]{2}{*}{$\begin{array}{l}\text { Sig (2 } \\
\text { tailed) }\end{array}$} \\
\hline & & & & Lower & Upper & & & \\
\hline $\begin{array}{l}\text { Pretest- } \\
\text { Posttest }\end{array}$ & $-9,000$ & 8,462 & 1,430 & $-11,907$ & $-6,093$ & $-6,292$ & 34 & 0,000 \\
\hline
\end{tabular}

Berdasarkan statistik deskriptif yang telah dibahas sebelumnya, rata-rata pretest sebesar 37,14 dan rata-rata postest sebesar 46,14 maka dapat disimpulkan bahwa terdapat perbedaan antara pretest dan postest sebesar 9,00. Hal ini menunjukkan bahwa terdapat perbedaan nilai mahasiswa sebelum dan setelah diberikan materi Sejarah Komputer. Tabel 5 merupakan hasil uji hipotesis Paired T-Test dengan taraf kepercayaan $95 \%$ maka diperoleh nilai signifikasi $0,000<0,05$, maka hipotesis diterima. Dengan demikian maka dapat disimpulkan bahwa terdapat peningkatan hasil belajar siswa sebelum dan setelah diterapkan materi sejarah komputer.

Table 6. Paired T-Test Kelas Kontrol

\begin{tabular}{|c|c|c|c|c|c|c|c|c|}
\hline & \multicolumn{8}{|c|}{ Paired Differences } \\
\hline & \multirow[t]{2}{*}{ Mean } & \multirow[t]{2}{*}{$\begin{array}{c}\text { Std. } \\
\text { Deviasi }\end{array}$} & \multirow{2}{*}{$\begin{array}{l}\text { Std. } \\
\text { Error } \\
\text { Mean }\end{array}$} & \multicolumn{2}{|c|}{$\begin{array}{l}95 \% \text { Confidence } \\
\text { Interval of the } \\
\text { Difference }\end{array}$} & \multirow[t]{2}{*}{$\mathbf{T}$} & \multirow[t]{2}{*}{ Df } & \multirow[t]{2}{*}{$\begin{array}{l}\text { Sig (2 } \\
\text { tailed) }\end{array}$} \\
\hline & & & & Lower & Upper & & & \\
\hline $\begin{array}{l}\text { Pretest- } \\
\text { Posttest }\end{array}$ & $-11,951$ & 11,314 & 1,912 & $-15,838$ & $-8,065$ & $-6,249$ & 34 & 0,000 \\
\hline
\end{tabular}

Berdasarkan statistik deskriptif yang telah dibahas sebelumnya, rata - rata pretest pada kelas kontrol sebesar 24,33 dan rata - rata postest sebesar 36,29 maka dapat disimpulkan bahwa terdapat perbedaan antara pretest dan postest sebesar 11,96. Hal ini menunjukkan bahwa terdapat perbedaan nilai mahasiswa sebelum dan setelah diterapkan media pembelajaran interaktif ispring pada materi sejarah komputer Tabel 6 merupakan hasil uji hipotesis Paired T-Test dengan taraf kepercayaan 95\% maka diperoleh nilai signifikasi $0,000<0,05$, maka hipotesis diterima. Dengan demikian maka dapat disimpulkan bahwa terdapat peningkatan hasil belajar siswa sebelum dan setelah diterapkan media pembelajaran menggunakan Ispring pada materi sejarah komputer. Hal ini disebabkan oleh beberapa faktor yaitu sebagai berikut.

Pertama, media interaktif dengan menggunakan Ispring yang dikembangkan dapat membantu mahasiswa dalam belajar. Media interaktif ini layak diterapkan dalam pembelajaran disebabkan karena mahasiswa dimudahkan dalam memahami materi pembelajaran. Media ini terdapat beberapa komponen seperti teks, audi, gambar yang menunjang isi dari materi pembelajaran. Media pembelajaran interaktif berbasis ispring 
merupakan media yang dapat digunakan sebagai media alternatif dalam pembelajaran. Ispring merupakan media yang praktis dan efektida digunakan untuk meningkatkan kemandirian siswa (Ariyanti et al., 2020). Penggunaan media pembelajaran dapat memberikan dampak positif dalam pembelajaran (Desimyari, Putra, \& Manuaba, 2018; Rahmi, Budiman, \& Widyaningrum, 2019). Komponen tersebut memberikan stimulus kepada mahasiswa dalam merangsang alat indranya (Armansyah, Sulton, \& Sulthoni, 2019; Novitasari, 2016). Semakin banyak komponen yang digunakan maka akan semakin besar informasi yang diperoleh dapat diingat dan dipahami. Sehingga mahasiswa dapat menerima dan menyerap informasi pelajaran melalui media interaktif yang dikembangkan. Selain itu, mahasiswa juga sangat mudah dalam mengoperasikan media interaktif yang dikembangkan sehingga merasa mudah dan nyaman dalam belajar.

Kedua, media interaktif dengan menggunakan Ispring yang dikembangkan meningkatkan motivasi mahasiswa dalam belajar. Media pembelajaran interaktif berbasis ispring menjadikan pembelajaran menjadi lebih menyenangkan dan melatih mahasiswa mandiri serta mampu untuk meningkatkan kreativitas. Tampilan media interaktif yang menarik dan tidak membosankan membuat siswa lebih termotivasi dalam belajar. Desain yang menarik, kelengkapan dan kesesuaian materi dalam media interaktif ini membuat mahasiswa merasa tertarik dan termotivasi dalam belajar dengan berbantuan media ini (Bardi \& Jailani, 2015; Suryanda, Ernawati, \& Maulana, 2016). Hal ini disebabkan karena penyajian materi dengan audio maupun visual. Pemanfaatkan teknologi dalam pembelajaran dapat meningkatkan kualitas proses pembelajaran (Darmalaksana, Hambali, Masrur, \& Muhlas, 2020; Utami \& Hasanah, 2019). Pada aspek visual media ini yaitu tampilan, gambar, teks, dan audio, ini mempermudah penyampaian informasi membantu mahasiswa dalam memahami informasi yang diberikan sehingga meningkatkan motivasi siswa dalam belajar.

Berdasarkan data tersebut dapat ditarik kesimpulan bahwa penggunaan media pembelajaran memiliki peningkatan yang signifikan. Hal tersebut sesuai dengan penelitian yang dilakukan oleh Arpan, Sulistiyarini, \& Santoso (2016) dan Winarni \& Astuti (2019) yaitu terdapat pengaruh kreativitas terhadap hasil belajar setelah menerapkan media pembelajaran. Sejalan dengan hasil penelitian ini, penelitian yang dilakukan oleh Alfiyansah (2016), Sastrakusumah, Suherman, Darmawan, \& Jamila (2018) dan Hadi, Yahya, \& Lufthansa (2019) menyatakan bahwa penggunaan media berbasis ispring dapat meningkatkan hasil belajar, motivasi dan kemampuan berpikir kritis siswa dalam pembelajaran. Berdasarkan hasil tersebut, implikasi penelitian ini yaitu penggunaan media ispring dalam pembelajaran memberikan pengaruh positif sehingga dapat digunakan pada pembelajaran lanjutan dan dapat dikembangkan untuk materi maupun mata kuliah lainnya.

\section{Simpulan}

Media pembelajaran interaktif menggunakan Ispring berpengaruh terhadap hasil belajar mahasiswa. Dapat disimpulkan bahwa media pembelajaran interaktif menggunakan Ispring meningkatkan hasil belajar mahasiswa pada materi sejarah komputer.

\section{Daftar Pustaka}

Alfiyansah, R. (2016). Penggunaan Media Pembeljaran I-Spring Presenter Untuk Meningkatkan Motivasi Belajar dan Hasil Belajar Pada Mata Kuliah Keperawatan Dasar Nutrisi. Pedagogia: Jurnal IImu Pendidikan, 14(2). https://doi.org/https://doi.org/10.17509/pedagogia.v14i2.3886

Antara, Kristiantari, \& Suadnyana. (2017). Pengaruh Model Pembelajaran Talking Stick Berbantuan Rubrik Surat Kabar Terhadap Keterampilan Berbicara. International Journal Of Elementary Education, 4(1), 290-297. 
https://doi.org/http://dx.doi.org/10.23887/ijee.v1i4.12960.

Ariyanti, D., Mustaji, \& Harwanto. (2020). Multimedia Interaktif Berbasis Ispring Suite 8. Jurnal Education and Development, 1(8). Retrieved from http://journal.ipts.ac.id/index.php/ED/article/view/1727

Armansyah, F., Sulton, S., \& Sulthoni, S. (2019). Multimedia Interaktif Sebagai Media Visualisasi Dasar-Dasar Animasi. Jurnal Kajian Teknologi Pendidikan, 2(3), 224 229. https://doi.org/10.17977/um038v2i32019p224

Arpan, M., Sulistiyarini, D., \& Santoso, D. (2016). Effect of Motivation and Creativity on Students' Psychomotor Ability. Journal of Education, Teaching and Learning, 1(2). https://doi.org/https://dx.doi.org/10.26737/jetl.v1i2.42

Bardi, \& Jailani. (2015). Pengembangan Multimedia Berbasis Komputer Untuk Pembelajaran Matematika Bagi Siswa SMA Pendidikan. Jurnal Inovasi Teknologi, 2(1), 49-63. https://doi.org/https://doi.org/10.21831/tp.v2i1.5203

Dadri, P. C. W., \& Putra, D. (2017). Pengaruh Model Pembelajaran Kooperatif Tipe Numbered Head Together (NHT) Terhadap Hasil Belajar Matematika Kelas IV. International Journal of Elementary Education, 5(2), 1-10. https://doi.org/http://dx.doi.org/10.23887/ijee.v3i2.18517

Darmalaksana, W., Hambali, R. Y. A., Masrur, A., \& Muhlas. (2020). Analisis Pembelajaran Online Masa WFH Pandemic Covid-19 sebagai Tantangan Pemimpin Digital Abad 21. Karya Tulis IImiah (KTI) Masa Work From Home (WFH) Covid-19 UIN Sunan Gunung Djati Bandung Tahun 2020, 1(1), 1-12.

Desimyari, Putra, \& Manuaba. (2018). Pengaruh Model Think Talk Write Berbantuan Media Audio Visual Terhadap Keterampilan Menulis Siswa. International Journal of Elementy Education, 2(3), https://doi.org/http://dx.doi.org/10.23887/ijee.v2i3.15969

Dewi, C. (2017). Peningkatan Keterampilan Berbicara Dalam Bermain Drama Melalui Model Pembelajaran Kooperatif Tipe Inside-Outside Circle. Jurnal Inovasi Pembelajaran, 3(2). https://doi.org/https://doi.org/10.22219/jinop.v3i2.4575

Donas, \& Elhefni. (2016). Pengaruh Penerapan Pembelajaran Bermakna (Meaningfull Learning) Pada Pembelajaran Tematik IPS Terpadu Terhadap Hasil Belajar Siswa Kelas III di MI Ahliyah IV Palembang. JIP: Jurnal IImiah PGMI, 2(1), 19-28. Retrieved from http://jurnal.radenfatah.ac.id/index.php/jip/article/view/1063

Geni, K. H. Y. W., Sudarma, I. K., \& Mahadewi, L. P. P. (2020). Pengembangan Multimedia Pembelajaran Interaktif Berpendekatan CTL Pada Pembelajaran Tematik Siswa Kelas IV SD. Edutech Universitas Pendidikan Ganesha, 8, 1-16.

Gunawan, G., Sahidu, H., Harjono, A., \& Suranti, N. M. Y. (2017). The effect of project based learning with virtual media assistance on student's creativity in physics. Jurnal Cakrawala Pendidikan, (2).

Hadi, Yahya, \& Lufthansa. (2019). Pengembangan Media Pembelajaran Berbasis Ispring Suite 8 Pada Materi Perwasitan Matakuliah Teori dan Praktek Bola Voli 1 Tahun Akademik. Jurnal Filsafat, Sains, Teknologi Dan Sosial Budaya, 25(1). Retrieved from http://ejurnal.budiutomomalang.ac.id/index.php/paradigma/article/view/559

Herayanti, L., Habibi, H., \& Fuaddunazmi, M. (2017). Pengembangan Media Pembelajaran Berbasis Moodle pada Matakuliah Fisika Dasar. Jurnal Cakrawala Pendidikan, 36(2), 210-219. https://doi.org/10.21831/cp.v36i2.13077

Karo-Karo, I. R., \& Rohani, R. (2018). Manfaat Media Dalam Pembelajaran. AXIOMA Jurnal Program Studi Pendidikan Matematika Universitas Islam Jember, 7(1). https://doi.org/http://dx.doi.org/10.30821/axiom.v7i1.1778 
Kuswanto, J., \& Walusfa, Y. (2017). Pengembangan Multimedia Pembelajaran pada Mata Pelajaran Teknologi Informasi dan Komunikasi Kelas VIII. Innovative Journal of Curriculum and Educational Technology IJCET, 6(2), 58-64. https://doi.org/https://doi.org/10.15294/ijcet.v6i2.19335

Lestari, Kristiantari, \& Ganing. (2017). Pengaruh Model Pembelajaran Talking Stick Berbantuan Lagu Daerah Terhadap Hasil Belajar IPS. International Journal Of Elementary Education, https://doi.org/http://dx.doi.org/10.23887/ijee.v1i4.12960.

$4(1)$.

Moma. (2017). Pengembangan Kemampuan Berpikir Kreatif dan Pemecahan Masalah Matematis Mahasiswa Melalui Metode Diskusi. Cakrawala Pendidikan, 36(1), 130139. Retrieved from https://journal.uny.ac.id/index.php/cp/article/view/10402/pdf

Mustafa, Murniati, \& Niswanto. (2018). Manajemen Sarana Pendidikan Pada Sekolah Anak Berkebutuhan Khusus Di SDLB YTC Kutablang Kabupaten Bireuen. Jurnal Administrasi Pendidikan, 6(1). Retrieved from http://jurnal.unsyiah.ac.id/JAP/article/view/11733

Nada, I., Utaminingsih, S., \& Ardianti, S. D. (2018). Penerapan Model Open Ended Problems Berbantuan Cd Pembelajaran Untuk Meningkatkan Kemampuan Berpikir Kreatif Siswa Kelas Iv Sd 1 Golantepus. Jurnal Pendidikan Sekolah Dasar, 4(2), 216. https://doi.org/10.30870/jpsd.v4i2.3856

Novitasari, D. (2016). Pengaruh Penggunaan Multimedia Interaktif Terhadap Kemampuan Pemahaman Konsep Matematis Siswa. Jurnal Pendidikan Matematika \& Matematika, 2(2), 8-18.

Primasari, R., Zulfiani, Z., \& Herlanti, Y. (2014). Penggunaan Media Pembelajaran Di Madrasah Aliah Negeri Se-Jakarta Selatan. Edusains, 6(1). https://doi.org/https://doi.org/10.15408/es.v6i1.1101

Puspitorini, Subali, \& Jumadi. (2014). Penggunaan Media Komik Dalam Pembelajaran IPA Untuk Meningkatkan Motivasi Dan Hasil Belajar Kognitif Dan Afektif. Cakrawala Pendidikan, 33(3), 413-420. Retrieved from https://journal.uny.ac.id/index.php/cp/article/view/2385/pdf

Rahmi, M. S. M., Budiman, M. A., \& Widyaningrum, A. (2019). Pengembangan Media Pembelajaran Interaktif Macromedia Flash 8 Pada Pembelajaran Tematik Tema Pengalamanku. International Journal Of Elementary Education, 3(2), 178-185. https://doi.org/10.23887/ijee.v3i2.18524

Renny, Sonbay, Yohana, R. (2019). the Effect of Open-Ended Teaching Model on Mathematics. Jurnal Kependidikan Matematika, 1(2), 105-110. Retrieved from https://journal.unwira.ac.id/index.php/ASIMTOT

Riyanto, W. D., \& Gunarhadi, G. (2017). The Effectiveness of Interactive Multimedia in Mathematic Learning: Utilizing Power Points for Students with Learning Disability. IJPTE: International Journal of Pedagogy and Teacher Education, 1(1), 55-63. https://doi.org/10.20961/ijpte.v1i1.8400

Santra, Putu, Citra Wibawa, I. M., \& Rati, N. W. (2018). Pengaruh Model Pembelajaran Think Pair Share Berbantuan Power Point Terhadap Hasil Belajar Ipa. Jurnal Imiah Pendidikan Dan Pembelajaran, 2(1), 307-315. https://doi.org/10.23887/jipp.v2i1.13975

Sastrakusumah, E. N., Suherman, U., Darmawan, D., \& Jamila, J. (2018). Pengaruh Media Pembelajaran Interaktif Berbantuan Aplikasi Ispring Presenter Terhadap Kemampuan Berpikir Kritis. Jurnal Teknologi Pendidikan Dan Pembelajaran, 3(1). https://doi.org/https://doi.org/10.31980/tp.v3i1.164 
Siddiq, Sudarma, \& Simamora. (2020). Pengembangan Animasi Dua Dimensi Pada Pembelajaran Tematik Untuk Siswa Kelas III Sekolah Dasar. Jurnal Edutech Undiksha, 8(2), 49-63. https://doi.org/http://dx.doi.org/10.23887/jeu.v8i2.28928

Suryanda, Ernawati, \& Maulana. (2016). Pengembangan Modul Multimedia Mobile Learning Dengan Android Studio 4.1 Materi Keanekaragaman Hayati Bagi Siswa Sma Kelas X. Jurnal Pendidikan Biologi, 9(1), 55-64. https://doi.org/https://doi.org/10.21009/biosferjpb.9-1.9

Susiana, R., \& Wening, S. (2015). Pengaruh Model Direct Instruction Berbantuan Multimedia Terhadap Motivasi Belajar Dan Pencapaian Kompetensi Pembuatan Desain Busana. Jurnal Vokasi Pendidikan, 5(3). https://doi.org/https://doi.org/10.21831/jpv.v5i3.6491

Utami, \& Hasanah. (2019). Kompetensi Profesional Guru Dalam Penerapan Pembelajaran Tematik Di SD Negeri Maguwoharjo 1 Yogyakarta. Pionir Jurnal Pendidikan, 8(2). https://doi.org/http://dx.doi.org/10.22373/pjp.v8i2.6232.

Winarni, R., \& Astuti, E. R. P. (2019). Pengaruh Penggunaan Media Pembelajaran Storyboard Terhadap Kreativitas Belajar Siswa Pada Mata Pelajaran Seni Budaya. Jurnal Teknologi Pendidikan, 4(2). Retrieved from https://ejournal.undikma.ac.id/index.php/jtp/article/view/2249/1572

Wulandari, Sudatha, \& Simamora. (2020). Pengembangan Pembelajaran Blended Pada Mata Kuliah Ahara Yoga Semester II di IHDN Denpasar. Jurnal Edutech Undiksha, 8(1), 1-15. https://doi.org/http://dx.doi.org/10.23887/jeu.v8i1.26459

Wungguli, D., \& Yahya, L. (2020). Pengaruh Penggunaan Media Berbasis Information and Communication Technology (ICT) terhadap Hasil Belajar Siswa pada Materi Dimensi Tiga. Jambura Journal of Mathematics Education, 1(1), 41-47. https://doi.org/10.34312/jmathedu.v1i1.5376 